\title{
Curcumin ve Meslektaşlarımızdan Beklediğimiz Editöre Mektuplar
}

\author{
Curcumin and the Letters to the Editor we Expect from our Colleagues
}

\section{Prof. Dr. Türkan Kutluay Merdol ${ }^{1}$}

\section{GíRiş}

Son ylllarda, içlerindeki etken maddeler nedeniyle, zerdeçal, zencefil ve tarçın gibi bitkisel kaynaklı bazı besinlerin; kendileri, tozları ya da onların kaynatılması ile yapılan çaylarla hazırlanan ürünlerinin, insan yapımı sentetik ilaçlardan daha üstün olduğu inancı ile, farklı kültürlerde yaygın olarak kullanıldığı, pek çok çalışma ile gösterilmiştir. Bahsi geçen ürünler, genellikle, kanser, Alzheimer, gibi hastalıklarda tıbbi tedaviye destek olarak kullanılmaktadır. Araştırmacılar bahsi geçen bu ürünlere atfedilen etkinin, bitkinin içindeki hangi kimyasal ögeden kaynaklandığı konusunda, çeşitli çalışmalar yürütmektedirler. Bugünkü editorial yazı için, bu besinlerden zerdeçalda (ing. Turmeric) bulunan kürkümin (ing. Curcumin) ile ilgili araştırma sonuçları üzerinde görüşlerimi açıklamak istedim. Kürkümin, Türkçe kaynaklarda "curcumin” olarak yerleşmeye başladığından, bundan sonra bu şekilde yazılacaktır.

\section{Curcumin Nedir?}

Curcumin, zerdeçal adlı bitkisel besinde, doğal olarak oluşan bir fitokimyasaldır ve zerdeçal özü olarak anılır. Curcumin; üç curcuminoid gruptan oluşmaktadır. Bunlar diferülorometan, dimetoksikürin ve bismetoksikürüminindir. Curcuminde bu curcuminoid grupların yanı sira uçucu yağlar (tumeron, atlantion ve zingiberone), şekerler, proteinler ve reçineler vardır. Curcumin suda neredeyse çözünemeyen, ancak midenin asidik pH'sında oldukça kararlı olan lipofilik bir polifenoldür. Hayvan çalışmaları, curcuminin hızla metabolize olduğunu, karaciğerde konjüge edilip dışkı ile atıldığını, bu nedenle sinırlı sistemik biyoyarlılığı olduğunu göstermektedir. Ancak yapılan çalışmaların in vitro ve hayvan çalışmaları ile sınırlı oluşu, insanlar üzerinde etkinin ne kadar olduğu ve bu etki mekanizmasının hangi yolak üzerinde gerçekleştiği konusunda yapılan çalışmaların sinırlı oluşu, bir yorum çlkarmak için yeterli görünmemektedir. Yine de pek çok kültürde, çoğunlukla da kanser ve Alzheimer hastaları tarafından kullanıldığı yönünde veriler bulunması, hastaların diyetlerinden sorumlu diyetisyenler için bir yorum yapmayı zorunlu kılmaktadır. Bu konuda bir sonuç bildirmeden önce, meslektaşlarımız arasında bu konularda çalışan arkadaşlarımızın deneyimlerinden faydalanmanın daha doğru olacağını düşünerek, Türkiye’de kanser alanında, kanserli hastaların medikal diyet tedavileri konusunda klinik deneyimleri ile birlikte tümör biyolojisi ve spesifik besin öğelerinin ilişkisini in vivo ve in vitro olarak inceleyen deneysel onkoloji alanında da çalışmalarına devam eden meslektaşımız Dr. Öğr. Üyesi Rüksan Çehreli'den konu ile ilgili gözlemlerini ve bu konudaki görüşlerini bildiren bir "Editöre mektup" yazmasını rica ettim. Kendisi bana aşağıdaki özet yazıyı gönderdi, sizlere iletiyorum. Kanserli hasta beslenmesi üzerinde çalıştı̆̆ını bildiğim başka arkadaşlarımız da var. Umarım onlar için aydınlatıcı bir kaynak rolü görebilir yazılarımız. 


\section{Dr. Öğr. Üyesi Rüksan Çehreli’nin mektubu:}

Sayın Editör,

Çin ve Ayurveda tıbbında yaygın olarak kullanılan ve zerdeçal olarak bilinen Curcuma longa (turmeric) bitkisi, içerdiği demethoxycurcumin ve bisdemethoxycurcumin dahil olmak üzere curcuminoidler bakımından zengindir. Çeşitli farmakolojik özelliklere sahip bir fitopolifenol pigmenti olan curcumin ve kanser ilişkisinin son yıllarda artan bir heyecanla çok sayıda bilimsel çalışmalara konu olduğu literatürde görülmektedir (1).

Curcuminin farmakolojik özellikleri meme, servikal, kolon, gastrik, hepatik, lösemi, oral epitel, over, pankreas ve prostat gibi çeşitli kanser tiplerinden oluşan hücre hatlarında in vitro ve in vivo olarak farelerde inceleyen çalışmalarda anti-kanser aktivitesi çeşitli yolaklar üzerinden gösterilmiştir.

Curcuminin ayrıca, serbest radikallerin oluşumunu engellediği, siklooksijenazların (COX's) ve inflamasyon ile ilgili diğer enzimlerin inhibisyonunun bir sonucu olarak anti-enflamatuar özelliklere sahip olduğu ve protein kinaz C'nin inhibisyonu dahil olmak üzere çeşitli mekanizmalarla hücre sinyal transdüksiyonunu bozduğu belirtilmektedir. Bu etkiler, tümör hücresi proliferasyonunun inhibe olması ve apoptozis, angiogenez gibi karsinogenezin baskılanmasını ve tümör büyümesini engelleyen etkileri içermektedir $(1,2)$. Ancak bu özellikleri nedeniyle kemoterapi alan hastalarda kemoterapi ajanlarının etkinliğini bozabileceği de düşünülmektedir.

Son yıllardaki klinik çalışmalarda, kanserli hastaların tedavi süreçlerinde yaşanan komplikasyonları azaltmadaki rolleri ile ilgili olarak yeni bilgiler de tanımlanmaktadır. Curcuminoidlerin steroid metabolizması üzerindeki etkileri hakkında henüz çok fazla bilgi bulunmamaktadır. Pek çok anti-kanser ilacı, steroidojenik yoldaki enzimleri hedeflediğinden, curcuminoidlerin sitokrom P450, CYP17A1, CYP21A2 ve CYP19A1 enzim aktiviteleri üzerindeki etkisi test edilerek, $10 \mathrm{Pg} / \mathrm{ml}$ kullanıldığında, hem 17a-hidroksilaz hem de 17,20 liyaz CYP17A1 aktivitesini önemli ölçüde azalttığı görülmüştür $(2,3)$. $\mathrm{Bu}$ bize kanser hastalarının kemoterapi süreci içinde bu ürünü ne kadar dozda ve ne zaman almaları gerektiği sorusuna yanıt bulmamızı gerektirmektedir.

Bu çalışmalar, curcuminoidlerin, özellikle daha yüksek dozlarda, steroid metabolizmasının inhibisyonuna neden olabileceğini göstermektedir. Ayrıca, zerdeçal tozunun, kanser hücresinin gelişimini yavaşlatıcı bir destek maddesi olarak, son zamanlardaki artan kullanımının dikkatle izlenilmesini gerektirmektedir. Curcuminoidlerin steroid metabolizması üzerindeki etkileri için daha fazla değerlendirme gerekmektedir.

Curcuminin farmakokinetik etkisi incelendiğinde; oral curcuminin bioyararlılığının oldukça düşük olduğu çok iyi tanımlanmıştır. Curcumin, oral alımdan sonra büyük oranda gastrointestinal ve hepatik metabolizmaya maruz kalan büyük bir lipofilik moleküldür. Ancak ölçülebilir serum düzeyine 3600 mg’a kadar olan dozlarda bile ulaşlamamıştır. Curcumin sadece intestinal epitelyumda aktive olmaktadır ve glukuronide ve sülfat forma dönüşerek hızlıca atılmaktadır. İnsan plazmasında durağan değildir. Piperine (karabiberdeki bir alkaloid) ilavesi ile curcuminin bioyararlılığının artırıldığını gösteren çalışmalar bulunmaktadır $(1,3,4)$. Sağlıklı insanlarda curcuminin farmakokinetiğini değerlendirmek için yapılan çalışmalarda, bir kapsül formülasyonundaki curcuminin ne kadarının emildiği ve serumda serbest curcumin miktarının tespit edilemediği görülmüştür. Serumda, konjuge formlar olarakcurcuminglukuronid ve sülfat metabolitleri şeklinde test edilmiştir. Konjuge formlarin maksimum konsantrasyonu, oral uygulamadan 2-10 saat sonra görülmüştür. Bu sonuç, pre-klinik modellerde oral curcuminin sistemik biyolojik aktivitesinin dolaşımdaki konjugatlarından oluşabileceğini düşündürmektedir (4).

Hayvan modelleri, curcuminin kolorektal kanserde güçlü etkinliğini tanımlarken, kolorektal kanser hastalarında güvenliği ve tolere edilebilirliğini gösteren beş Faz I klinik çalışmasının yapılmasına neden olmuştur. Bugüne kadar yapılan klinik 
araştırmalarda, insanlarda bir günde tolere edilen maksimum doz 8000 mg kadar olmuştur. Bu sonuçlar Faz II çalışmalarının gelişmesine yol açmıştır. Çok sayıdaki çalışmaların sonucu curcuminin, kolon kanserinin kemoprevensiyonu için faydalı olabileceğini göstermektedir.

Curcumin'in COX-2'yi inhibe etme mekanizması ile temel olarak COX-2 inhibitörlerinden celecoxib, valdecocib ve rofecoxibden farklı olarak kardiyovasküler sorunlar için bir risk faktörü olmadığını da göstermektedir. Özellikle 5-fluoruouracil (5-FU), all trans retinoik asit, cisplatin, celecoxib ve doxorobucin gibi kemoterapi ajanları ile birlikte test edilmiştir. Kolorektal kanserli hastalarda 5-fluoruouracil (5-FU) tedavisine ek olarak günlük oral curcumin extrakt dozu; 440-2200 mg 4 ay süre ile uygulanması ile minimal yan etki olarak grade I ve II bulantı ve diyare görülmüştür. Ancak curcumin ince bağırsakta hızla glukuronide dönüşmektedir, bu nedenle, düzeyi ve metabolitleri plazma, idrar ve kan hücrelerinde saptanmamıştır $(4,5)$.

$\mathrm{Bu}$ çalışma sonuçları, klinik çalışmalarda her tümör hücresinin farklı davranacağını ve tümör heterojenitesini unutmadan, nedensellik ilişkisi içinde bilimsel tanımlanma sürecinin olması gerektiğini göstermektedir.

Ancak modern tıpta altın standart olarak kabul edilen randomize çift kör placebo destekli klinik çalışmaların sistematik olarak değerlendirilmesinde; araştırmacılar kanıtların gücüne dayanan terapilere A tipi kanıt verirler. Bu kanıt, bir klinik endikasyon için, belirli bir tedavinin önerildiğini ve hasta için önemli ölçüde fayda sağlamanın kesin olduğunu gösterir bir tanımlama olarak kabul edilir ve bu tanımlamaya göre hastalar için bulunulabilir.

Kanserli hastalar genellikle, kanser tedavisi sırasında destekleyici olarak ve tedaviyle ilişkili yan etkileri yönetmek için tamamlayıcı tedavileri kullanır. Bununla birlikte, bu tür tedavilerin kullanımını destekleyen kanıtlar çok sinırlıdır. Ancak az sayıdaki klinik çalışmalardan elde edilen sonuçlara dayanarak, yaşam kalitesini artırmak için, çok dikkatle değerlendirilmelidir.

Klinisyenlerin hastaları için, meme, kolon, over, akciğer,prostatkanseritedavisisırasındavesonrasında belirli bir klinik uygulama için tamamlayıcı tedavi amacıyla curcuminin kullanılıp kullanılmayacağı, nasıl ve hangi dozlarda kullanılacağı hakkında bilinçli kararlar vermeleri için kanıta dayalı bilgilerin toplanması gerekmektedir $(6,7)$.

$\mathrm{Bu}$ konuda klinik çalışmalara artan bir gereksinim vardır ve özellikle her tümörün ve tümör hücresinin farklı davranabileceği unutulmadan özgün çalışmalar yapılması çok önemli olacaktır. Bu amaçla, Amerikan Ulusal Kanser Enstitüsü (National Cancer Institute, $\mathrm{NCI}$ ) tarafından desteklenen projeler ve halen devam eden çok merkezli klinik çalışmalar bulunmaktadır. Aşağıdaki devam eden klinik çalışma örnekleri; NCI web sayfasından izlenebilir $(8,9)$.

"Curcumin in Reducing Joint Pain in Breast Cancer Survivors with Aromatase Inhibitor-Induced Joint Disease” Faz 1 çalışması...

"Curcumin and Piperine in Reducing Inflammation for Ureteral Stent-Induced Symptoms in Patients with Cancer” Pilot Faz 1 çalışması.

"Curcumin in Preventing Gastric Cancer in Patients with Chronic Atrophic Gastritis or Gastric Intestinal Metaplasia” Randomize Faz IIb .

"Curcumin in Treating Patients with Prostate Cancer That Was Removed by Surgery" Randomize Faz IIb çalışması.

Sonuç olarak; “Doğalbir ürün güvenlibir ürün anlamına gelmez”. Bitkisel desteklerin içindeki moleküller, vücutta ilaçlar gibi hareket edebilir, bu nedenle diğer moleküller ile birlikte veya yüksek dozlarda alındığında zararlı yan etkileri görülebilir. Tümör biyolojisinde besin ögelerinin moleküler hedefleri çok çeşitli olabilir. Günümüzde tanımlanabilen kanıtlar ile kanserli hastalarda tümörün tipine ve kişiye özel değerlendirmeler ile tercihen zerdeçal olarak ve toz formunun en fazla bir tatlı kaşığı (5- 
10 g) kullanılmasını önerebiliriz. Ancak hastaların ve klinisyenlerin curcuminin tablet formunu yüksek dozlarda kullanmaları durumunda yukarıda belirtmeye çalıştığım nedenlerle oldukça önemli yan etkiler oluşturabilir. Tümöre özgü klinik çalışma sonuçları tamamlanıncaya kadar, tablet formunun kullanılması, ancak onkolog ve onkoloji alaninda uzmanlaşmış diyet uzmanlarının önerisi ile kontrol altında çok dikkatli bir şekilde değerlendirilmelidir.

\section{KAYNAKLAR}

1. Kunnumakkara AB, Harsha C, Banik K, Vikkurthi R, Sailo BL, Bordoloi D, et al. Curcumin bioavailability, a problem in humans: lessons from clinical trials. Expert Opin Drug Metab Toxicol. 2019;15(9):705-33.

2. Castaño PR, Parween S, Pandey AV. Bioactivity of curcumin on the cytochrome P450 enzymes of the steroidogenic pathway. Int J Mol Sci. 2019;20(18):460.

3. Panahi Y, Hosseini MS, Khalili N, Naimi E, Majeed M, Sahebkar A. Antioxidant and anti-inflammatory effects of curcuminoid-piperine combination in subjects with metabolic syndrome: A randomized controlled trial and an updated meta-analysis. Clin Nutr. 2015; 34:1101-8.

4. Adiwidjaja J, McLachlan AJ, Boddy AV. Curcumin as a clinically-promising anti-cancer agent: pharmacokinetics and drug interactions. Expert Opin Drug Metab Toxicol. 2017;13(9):953-72.

5. Johnson JJ, Mukhtar H. Curcumin for chemoprevention of colon cancer. Cancer Letters. 2007;255:170-81.

6. Greenlee H, Melissa J, DuPont-Reyes MPH, MPhil Lynda G, Balneaves RN, Linda E, et al. Clinical Practice Guidelines on the Evidence-Based Use of Integrative Therapies During and After Breast Cancer Treatment. CA Cancer J Clin. 2017;67:194-232.

7. Witt CA, Balneaves LG, Cardoso MJ, Cohen L, Greenlee $\mathrm{H}$, Johnston $\mathrm{P}$, et al. A Comprehensive Definition for Integrative Oncology. J Natl Cancer Inst Monogr. 2017; 1:2017(52).

8. National Cancer Institute. Office of Complemantary and Alternative Medicine: Research Resources. Available at: https://cam.cancer.gov/international_affairs/research_ resources.htm\#h04 Accessed December 26, 2019.

9. National Cancer Institute. Search Link. Available at: https://www.cancer.gov/search/results Accessed December 26, 2019.

Dr. Öğr.Üyesi Rüksan Çehreli,

Dokuz Eylül Üniversitesi

Onkoloji Enstitüsü

Prevantif Onkoloji Anabilim Dalı

İnciraltı, Izmir, Türkiye

e-mail: ruksan.cehreli@deu.edu.tr

\section{SONUÇ}

Sayın Çehreli'ye teşekkür ediyoruz. Diyetisyen meslektaşlarımızın curcumini, tıbbi tedavi uygulayan ekiple görüşmeden önermemesi, görüşme sonunda önerilmesi kararı alınması durumunda, hastanın beslenme ve diyet planının doğru yapılabilmesi için hasta dosyasının dikkatle okunması ve mümkünse hasta ile, değilse hasta yakınları ile görüşülerek, hastanın durumunun çok iyi değerlendirilmesi gerektiğini vurgulayabiliriz. Bundan böyle, branşlaşmolunda daha hızlı ilerleyebilmemiz adına, kendisini makaleleriyle, kitaplarıyla, katıldığı kongre ve seminerlerde sunduğu bildirilerle, seçtiği alanda uzman olduğunu kanıtlayan meslektaşlarımızdan, editöre mektup göndermelerini beklediğimizi ve bu mektuplara gerektiğinde bu köşede yer vereceğimizi bildirmek isteriz. Son yıllarda Türkiye'de Bariatrik cerrahi girişimleri artmaya başladı. Hastaların cerrahi sonrası izlenmesinde diyetisyen hayati bir rol oynamaktadır. Ancak, ameliyat geçiren hastaların böyle bir takibe alınmadığı yönünde çok duyumlar almaktayız. Bu nedenle, bundan sonraki editorial yazıda bu konudaki görüşlerinizi değerlendirmeyi dilerim. 